Article

\title{
The First Chelate-Free Crystal Structure of a Silicide Transition Metal Complex $\left[\mathrm{K}_{0.28} \mathrm{Rb}_{7.72} \mathrm{Si} 9 \mathrm{Ni}(\mathrm{CO})_{2}\right]_{2} \cdot \mathbf{1 6}_{3} \mathrm{NH}_{3}$
}

\author{
Stefanie Gärtner, Markus Hamberger and Nikolaus Korber * \\ Institute of Inorganic Chemistry, University of Regensburg, 93040 Regensburg, Germany; \\ E-Mails: stefanie.gaertner@ur.de (S.G.); markus.hamberger@ur.de (M.H.) \\ * Author to whom correspondence should be addressed; E-Mail: nikolaus.korber@ur.de; \\ Tel.: +49-941-943-4448; Fax: +49-941-943-1812.
}

Academic Editor: Helmut Cölfen

Received: 10 April 2015 / Accepted: 5 June 2015 / Published: 24 June 2015

\begin{abstract}
Single-crystals X-ray structure analysis of very thermally labile and moisture sensitive ammoniate crystals of $\left[\mathrm{K}_{0.28} \mathrm{Rb}_{7.72} \mathrm{SigNi}(\mathrm{CO})_{2}\right]_{2} \cdot 16 \mathrm{NH}_{3}$ show the presence of the very rarely observed nickel-silicide complex $\left[\left\{\mathrm{Ni}(\mathrm{CO})_{2}\right\}_{2}(\mu-\mathrm{Si})_{2}\right]^{8-}$, which was up to now only known in the 18-crown-6 involving solid [Rb@18-crown-6)]2[K@18-crown$6)]_{2} \mathrm{Rb}_{4}\left[\left\{\mathrm{Ni}(\mathrm{CO})_{2}\right\}_{2}(\mu-\mathrm{Si})_{2}\right] \cdot 22 \mathrm{NH}_{3}$. This shows that, like already known for the heavier homologues, the presence of 18 -crown-6 $(1,4,7,10,13,16$-hexaoxacyclooctadecane) is no precondition for the stabilization of the silicide cluster anion in solid state and the absence of the alkali metal ligand even allows for the crystallization in the higher symmetric monoclinic space group $C 2 / c$ compared to the triclinic space group P-1 when 18-crown-6 is present.
\end{abstract}

Keywords: silicides; ammonia; crystal structure; cluster compounds; Zintl ions

\section{Introduction}

Homoatomic polyanions of group 14 elements represent naked, anionic elemental building blocks and are an intriguing field of main group chemistry due to their versatile reaction possibilities. They can be used as promising starting materials for the synthesis of new compounds, and especially the monocapped square antiprismatic shaped nine atom cluster anions $\mathrm{E}_{9}{ }^{4-}$ show a wide synthetic potential [1-4]. For the heavier homologues of this group, germanium, tin and lead, an abundance of 
beautiful examples can be found in literature, reaching from coupled clusters [5] over alkylated derivatives [6,7] ending at the involvement of transition metals, where the cluster is acting as a ligand (sometimes under rearrangement of the atoms yielding new cluster shapes) [8] and even endohedral metalloids are formed [9,10] (for a recent overview see [1]). The case is different for the lighter homologue silicon, of which a solution chemistry has only been known since 2004 [11-14] and very few examples of reactions are known up to now. Therefore, only a diminutive number of products, a total of three, have been characterized. In addition to $\left[\mathrm{Si}_{9} \mathrm{ZnPh}\right]^{3-}[15]\left(\mathrm{Ph}=\right.$ phenyl $\left.=\mathrm{C}_{6} \mathrm{H}_{5}\right)$ and $\left[(\mathrm{MesCu})_{2} \mathrm{Si}_{4}\right]^{4-}[16]$ (Mes $=$ mesitylene $\left.=\mathrm{C}_{6} \mathrm{H}_{2}\left(\mathrm{CH}_{3}\right)_{3}\right)$ ) (Figure 1a,b), where organometallic precursors have been used during synthesis, we previously could show that the $\mathrm{Si}_{9}{ }^{4-}$ cluster anions act as ligands in a simple ligand-exchange reaction of triphenylphosphine in the transition metal complex $\mathrm{Ni}(\mathrm{CO})_{2}\left(\mathrm{PPh}_{3}\right)_{2}\left(\mathrm{PPh}_{3}=\right.$ triphenylphosphine $\left.=\mathrm{P}\left(\mathrm{C}_{6} \mathrm{H}_{5}\right)_{3}\right)$ yielding the new complex $\left[\left\{\mathrm{Ni}(\mathrm{CO})_{2}\right\}_{2}\left(\mu-\mathrm{Si}_{9}\right)_{2}\right]^{8-}[17]$ (Figure 1c). All hitherto known crystal structures have the involvement of chelating additives in common, which are used during synthesis for the enhancement of the solubility of the Zintl educt material $\mathrm{A}_{12} \mathrm{Si}_{17}$ [18,19]. The question arose whether 18-crown-6 $(1,4,7,10,13,16$-hexaoxacyclooctadecane $) \quad$ or $\quad$ [2.2.2]-cryptand $\quad(4,7,13,16,21,24$-hexaoxa-1,10diazabicyclo[8.8.8]hexacosane) are imperatively necessary for the stabilization of the complex anion in the crystal structures. We here present the fourth crystal structure at all of a silicide complex anion in the crystal structure of $\left[\mathrm{K}_{0.28} \mathrm{Rb}_{7.72} \mathrm{Si}{ }_{9} \mathrm{Ni}(\mathrm{CO})_{2}\right]_{2} \cdot 16 \mathrm{NH}_{3}$, which proves the stability of the transition metal complex in a rigid cation-anion-ammonia network without any further chelating additives.

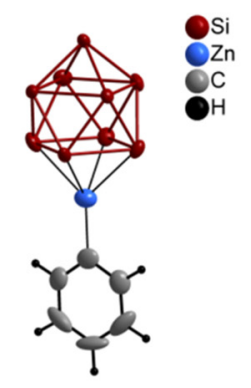

(a)

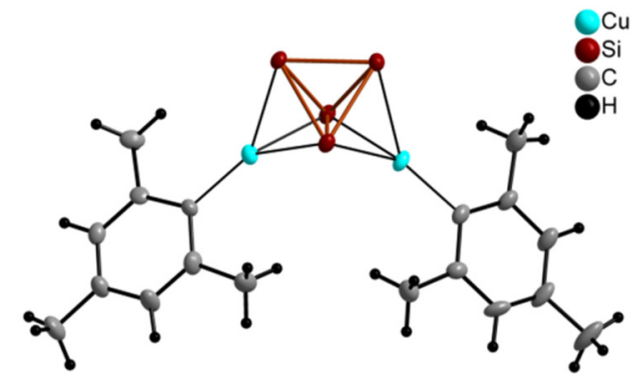

(b)

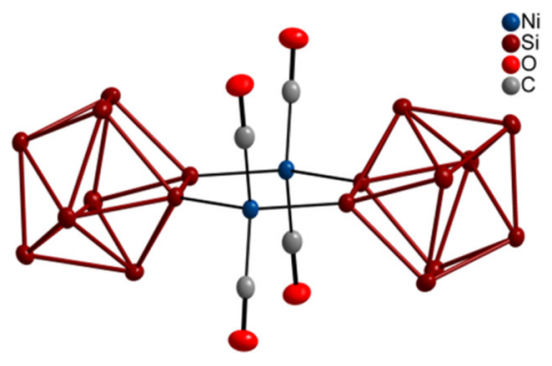

(c)

Figure 1. Silicon cage anions in transition metal complexes: (a) $[\mathrm{Si} \text { ZnPh }]^{3-}[15]$; (b) $\left[(\mathrm{MesCu})_{2} \mathrm{Si}_{4}\right]^{4-}[16] ;(\mathbf{c})\left[\left\{\mathrm{Ni}(\mathrm{CO})_{2}\right\}_{2}\left(\mu-\mathrm{Si}_{9}\right)_{2}\right]^{8-}[17]$.

\section{Results and Discussion}

The reaction of the ternary Zintl material $\mathrm{K}_{6} \mathrm{Rb}_{6} \mathrm{Si}_{17}$ and $\mathrm{Ni}(\mathrm{CO})_{2}\left(\mathrm{PPh}_{3}\right)_{2}$ in the presence of 18 -crown-6 resulted in the first chelate free crystal structure of the silicide transition metal complex $\left[\left\{\mathrm{Ni}(\mathrm{CO})_{2}\right\}_{2}(\mu-\mathrm{Si})_{2}\right]^{8^{-}}$and proves the stability of the complex in the solid state, independently from 18-crown-6. Although 18-crown-6 is absent in the crystal structure of the here discussed compound, an even larger excess was used during the synthesis, compared to the synthesis of the 18 -crown- 6 involving material. This might indicate the basic necessity of the chelating additive for a better solubility of the precursor material but disproves its stabilizing effects in solid state. In the following, the new compound $\left[\mathrm{K}_{0.28} \mathrm{Rb}_{7.72} \mathrm{Si}{ }_{9} \mathrm{Ni}(\mathrm{CO})_{2}\right]_{2} \cdot 16 \mathrm{NH}_{3}(\mathbf{1})$ is compared to the known crystal structure of [Rb@18-crown-6 $]_{2}[\mathrm{~K} @ 18 \text {-crown-6 }]_{2} \mathrm{Rb} 4\left[\left\{\mathrm{Ni}(\mathrm{CO})_{2}\right\}_{2}(\mu-\mathrm{Si})_{2}\right] \cdot 22 \mathrm{NH}_{3}$ (2) in order to analyze similarities 
and discrepancies in the crystal structures of both compounds. As the mixed-cationic compound $\mathrm{K}_{6} \mathrm{Rb}_{6} \mathrm{Si}_{17}$ was used during synthesis, the positions of all cations were carefully investigated for mixed occupancy during the refinement using the derived electron density maps. A mixed cationic site could only be resolved for one cation site (Rb4/K4 0.725(7):0.275(7)), the remaining four crystallographically independent cation positions turned out to be exclusively occupied by rubidium. One cationic site $(\mathrm{Rb} 5)$ is located beside an inversion center within the glide plane (site coordinates $0.25,0.75,0.5$, Wyckoff position $4 c$ ) and therefore the s.o.f. (site occupancy factor) was fixed at 0.5 . The crystal data and details of the structure refinement are given in Table 1.

Table 1. Crystal data and structure refinement details for $\left[\mathrm{K}_{0.28} \mathrm{Rb}_{7.72} \mathrm{Si} 9 \mathrm{Ni}(\mathrm{CO})_{2}\right]_{2} \cdot 16 \mathrm{NH}_{3}(\mathbf{1})$.

\begin{tabular}{|c|c|}
\hline Item & Numerical Value \\
\hline CCDC No. & 1043014 \\
\hline Chemical formula & {$\left[\mathrm{K}_{0.28} \mathrm{Rb}_{7.72} \mathrm{Si}_{9} \mathrm{Ni}(\mathrm{CO})_{2}\right]_{2} \cdot 16 \mathrm{NH}_{3}$} \\
\hline $\operatorname{Mr}\left(\mathrm{g} \cdot \mathrm{mol}^{-1}\right)$ & 1678.63 \\
\hline Temperature (K) & $123(2)$ \\
\hline Crystal system & monoclinic \\
\hline Space group & $C 2 / c$ \\
\hline$a(\AA)$ & $30.669(6)$ \\
\hline$b(\AA)$ & $9.919(2)$ \\
\hline$c(\AA)$ & $19.894(4)$ \\
\hline$\alpha\left(^{\circ}\right)$ & 90 \\
\hline$\beta\left(^{\circ}\right)$ & $110.18(3)$ \\
\hline$\gamma\left(\left(^{\circ}\right)\right.$ & 90 \\
\hline$V\left(\AA^{3}\right)$ & $5680(2)$ \\
\hline Z & 4 \\
\hline$\rho_{\text {calc }}\left(\mathrm{g} / \mathrm{cm}^{3}\right)$ & 1.963 \\
\hline$\mu\left(\mathrm{mm}^{-1}\right)$ & 7.676 \\
\hline$F(000)(\mathrm{e})$ & 3260.0 \\
\hline Crystal size $\left(\mathrm{mm}^{3}\right)$ & $0.18 \times 0.12 \times 0.1$ \\
\hline Radiation & $\operatorname{MoK} \alpha(\lambda=0.71073)$ \\
\hline $2 \Theta$ range for data collection $\left(^{\circ}\right)$ & 4.636 to 55.28 \\
\hline Index ranges & $-39 \leq h \leq 39,-12 \leq k \leq 12,-25 \leq l \leq 25$ \\
\hline Reflections collected & 46,537 \\
\hline Independent reflections & $6534\left[R_{\text {int }}=0.0729, R_{\text {sigma }}=0.0523\right]$ \\
\hline Data/restraints/parameters & $6534 / 6 / 253$ \\
\hline Goodness-of-fit on $F^{2}$ & 0.954 \\
\hline$R_{1}, w R_{2}(I \geq 2 \sigma(I))$ & $R_{1}=0.0349, w R_{2}=0.0667$ \\
\hline$R_{1}, w R_{2}($ all data $)$ & $R_{1}=0.0568, w R_{2}=0.0711$ \\
\hline$\Delta \rho \max , \Delta \rho \min \left(\mathrm{e} \AA^{-3}\right)$ & $0.90 /-0.46$ \\
\hline
\end{tabular}

In both compounds, the complex anion $\left[\left\{\mathrm{Ni}(\mathrm{CO})_{2}\right\}_{2}(\mu-\mathrm{Si} 9)_{2}\right]^{8-}$ is located on an inversion center of space group $C 2 / c(1)$, respectively $P-1(2)$, and this results in very similar dimensions of the latter in both crystal structures (Figure 2, Table 2). This proves that the geometry of the anion is not affected by packing effects or cation-anion interaction. 


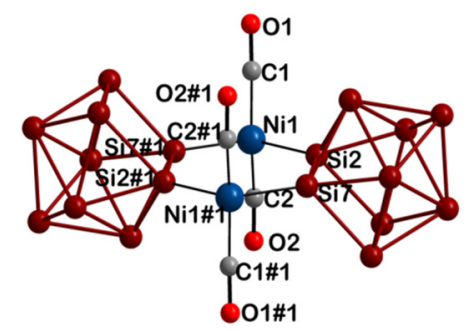

Figure 2. $\left[\left\{\mathrm{Ni}(\mathrm{CO})_{2}\right\}_{2}(\mu-\mathrm{Si})_{2}\right]^{8-}$ complex anion in $\mathbf{1}$ and 2; distances are given in Table 2.

Table 2. Distances within the complex anion $\left[\left\{\mathrm{Ni}(\mathrm{CO})_{2}\right\}_{2}(\mu-\mathrm{Si})_{2}\right]^{8-}$ in the two known crystal structures $\mathbf{1}$ and $\mathbf{2}$; atom assignment is given in Figure 2.

\begin{tabular}{cccccc}
\hline & $\mathbf{1}$ & & & $\mathbf{2}$ & \\
\hline Atom 1 & Atom 2 & Distance $(\boldsymbol{\AA})$ & Atom 1 & Atom 2 & Distance $(\boldsymbol{\AA})$ \\
\hline Ni1 & Si2 & $2.3052(12)$ & Ni1 & Si2 & $2.3033(17)$ \\
Ni1 & Si7 & $2.3044(13)$ & Ni1 & Si7 & $2.3001(18)$ \\
Ni1 & C1 & $1.738(4)$ & Ni1 & C1 & $1.743(8)$ \\
Ni1 & C2 & $1.746(4)$ & Ni1 & C2 & $1.729(6)$ \\
C1 & O1 & $1.167(5)$ & C1 & O1 & $1.169(8)$ \\
C2 & O2 & $1.159(5)$ & C2 & O2 & $1.183(8)$ \\
\hline
\end{tabular}

In 2, the complex anion shows direct contacts to six rubidium cations, two of which are symmetrically independent. A very similar arrangement is found for $\mathbf{1}$, but the absence of cation chelating crown ether molecules allows for more direct cation contacts (Figure 3). The anionic moiety in 2 exclusively shows contacts to rubidium, and the potassium cations are only coordinated by 18-crown-6 molecules and ammonia molecules, agreeing with the HSAB (hard and soft acids and bases) principle.

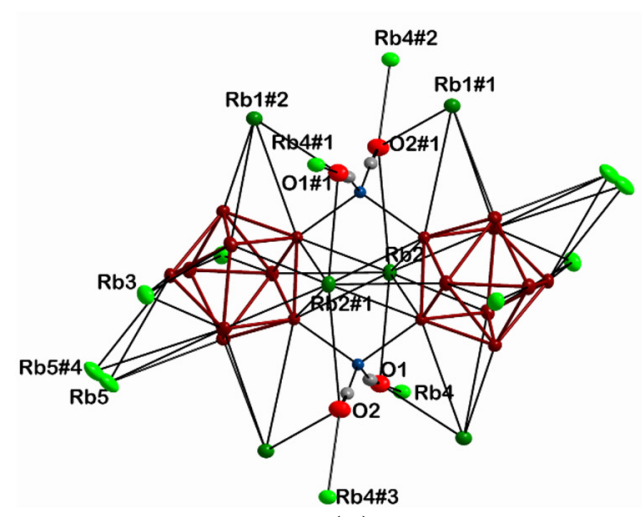

(a)

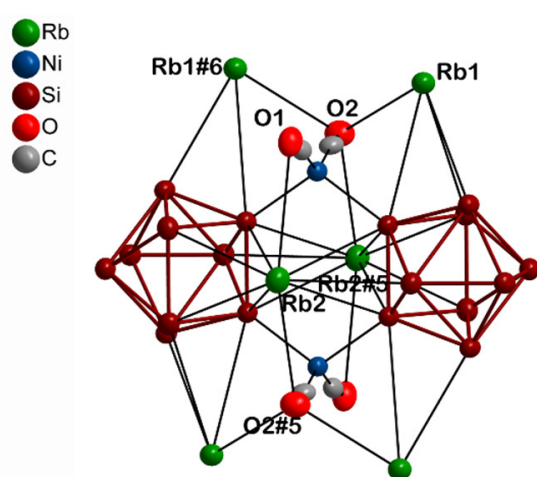

(b)

Figure 3. The comparison of the cation coordination of the complex anion $\left[\left\{\mathrm{Ni}(\mathrm{CO})_{2}\right\}_{2}(\mu-\mathrm{Si})_{2}\right]^{8-}$ in $\mathbf{1}$ (a) shows the presence of additional contacts (given in bright green) compared to the cation coordination of the complex anion $\left[\left\{\mathrm{Ni}(\mathrm{CO})_{2}\right\}_{2}(\mu-\mathrm{Si})_{2}\right]^{8^{-}}$in 2 (b). The position of Rb4 is mixedly occupied by rubidium and potassium (see text and Figure 3). Displacement ellipsoids are drawn at the 50\% probability level. (Symmetry codes: \#1: $1-x, 2-y, 1-z$; \#2: $x, 1+y, z$; \#3: $1-x, 1-y, 1-z$; \#4: $0.5-x, 1.5-y$, $1-z ; \# 5: 2-x, 1-y,-z ; \# 6: 1-x, 1-y, z)$. 
The shortest $\mathrm{Rb}-\mathrm{O}$ distances to the oxygen atoms of the carbonyl group of the complex anion in 2 are found at 3.275(5) $\AA(\mathrm{Rb} 2-\mathrm{O} 2 \# 2)$, whereas the lack of 18-crown-6 in 1 results in short $\mathrm{Rb}-\mathrm{O}$ distance of the carbonyl oxygen atoms $\mathrm{O} 1$ and $\mathrm{O} 2$ to the additional cationic site K4/Rb4 (see Table 3 ). Interestingly, the mixed occupancy perfectly agrees with the HSAB principle, as the smaller and therefore harder potassium prefers to coordinate to the small and hard oxygen atoms of the carbonyl ligand and short $\mathrm{K} / \mathrm{Rb}-\mathrm{O}$ distances can only be realized for this cationic site. The coordination of the cations is completed by contacts to the silicon atoms of the complex anion and ammonia molecules (Figure 4, Table 3). Altogether, a dense network of cations, anions and ammonia molecules is observed, which is also reflected by the calculated density of $1.963 \mathrm{~g} \cdot \mathrm{cm}^{-3}$ for $1 \mathrm{compared}$ to the value $1.517 \mathrm{~g} \cdot \mathrm{cm}^{-3}$ for 2 .
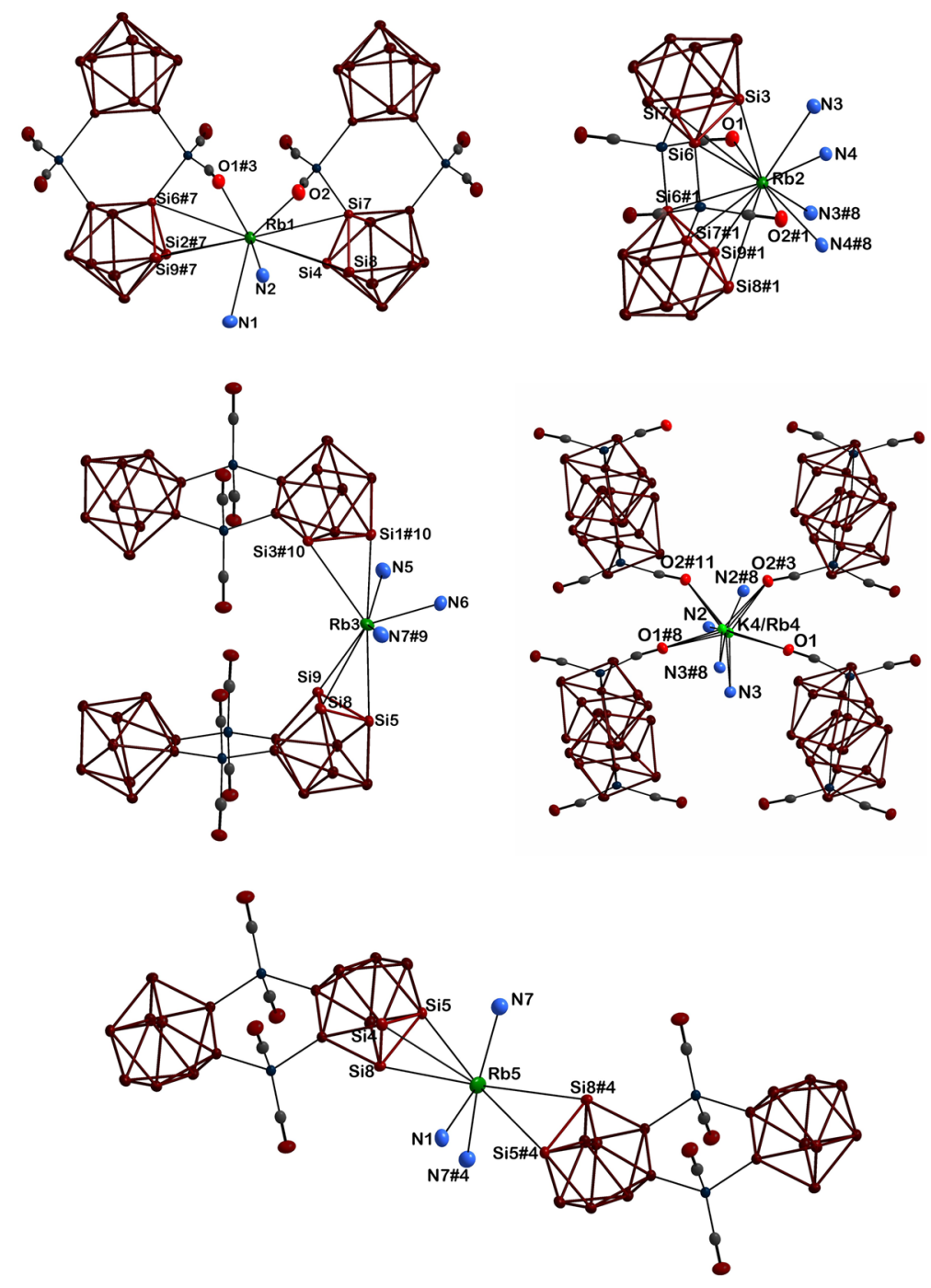

Figure 4. Coordination spheres of all five crystallographically independent cationic sites. The mixedly occupied cationic site K4/Rb4 shows only contacts to oxygen atoms of the carbonyl group and ammonia molecules, which agrees with the HSAB principle. The according distances are given in Table 2. Displacement ellipsoids are drawn at the $50 \%$ probability level, hydrogen atoms are omitted for clarity (Symmetry codes: \#1: $1-x, 2-y$, $1-z$; \#3: $1-x, 1-y, 1-z$; \#4: $0.5-x, 1.5-y, 1-z$; \#7: $x,-1+y, z$; \#8: $1-x, y, 0.5-z$; \#9: $0.5-x, 0.5+y, 0.5-z ; \# 10: x, 3-y,-0.5+z ; \# 11: x, 1-y,-0.5+z)$. 
Table 3. Distances for the coordination of the cations according to Figure 3.

\begin{tabular}{|c|c|c|c|c|c|}
\hline Atom 1 & Atom 2 & Distance $(\AA)$ & Atom 1 & Atom 2 & Distance (Å) \\
\hline \multirow{10}{*}{$\mathrm{Rb} 1$} & Si7 & $3.9366(14)$ & \multirow{4}{*}{$\mathrm{Rb} 4$} & N2 & $3.300(4)$ \\
\hline & Si9\#7 & $3.7493(15)$ & & N3 & $3.007(4)$ \\
\hline & Si2\#7 & $3.8338(14)$ & & $\mathrm{O} 1$ & $2.832(3)$ \\
\hline & $\mathrm{Si} 4$ & $3.6312(14)$ & & $\mathrm{O} 2 \# 3$ & $2.855(4)$ \\
\hline & $\mathrm{Si} 7$ & $3.9366(14)$ & \multirow{8}{*}{ K4 } & $\mathrm{O} 1$ & $2.70(3)$ \\
\hline & $\mathrm{Si} 8$ & $4.0366(15)$ & & $\mathrm{O} 1 \# 8$ & $2.99(3)$ \\
\hline & N2 & $3.116(4)$ & & $\mathrm{O} 2 \# 3$ & $2.79(2)$ \\
\hline & N1 & $3.322(4)$ & & $\mathrm{O} 2 \# 11$ & $2.98(2)$ \\
\hline & $\mathrm{O} 2$ & $3.853(4)$ & & $\mathrm{N} 2$ & $3.04(3)$ \\
\hline & $\mathrm{O} 1 \# 3$ & $3.241(4)$ & & $\mathrm{N} 2 \# 8$ & $3.58(2)$ \\
\hline \multirow{13}{*}{$\mathrm{Rb} 2$} & Si7\#1 & $3.5962(15)$ & & N3 & $2.776(17)$ \\
\hline & Si6\#1 & $3.5971(15)$ & & N3\#8 & $3.246(19)$ \\
\hline & Si6 & $3.8961(13)$ & \multirow{19}{*}{$\mathrm{Rb} 5 *$} & $\mathrm{Si} 5$ & $3.619(4)$ \\
\hline & $\mathrm{Si} 3$ & $3.4674(13)$ & & Si5\#4 & $3.639(4)$ \\
\hline & Si9\#1 & $3.5273(17)$ & & $\mathrm{Si} 4$ & $4.049(3)$ \\
\hline & Si8\#1 & $3.8988(17)$ & & Si8\#4 & $3.744(4)$ \\
\hline & Si7\#1 & $3.5961(15)$ & & Si8 & $3.988(3)$ \\
\hline & N3 & $3.406(4)$ & & N7 & $3.234(6)$ \\
\hline & N3\#8 & $3.367(4)$ & & N7\#4 & $3.222(6)$ \\
\hline & N4\#8 & $3.157(4)$ & & N1 & $3.258(5)$ \\
\hline & N4 & $3.090(4)$ & & & \\
\hline & $\mathrm{O} 1$ & $3.263(4)$ & & & \\
\hline & $\mathrm{O} 2 \# 1$ & $3.702(4)$ & & & \\
\hline \multirow{8}{*}{$\mathrm{Rb} 3$} & $\mathrm{Si} 5$ & $3.7988(13)$ & & & \\
\hline & Si1\#10 & $3.7609(14)$ & & & \\
\hline & Si8 & $3.6490(13)$ & & & \\
\hline & $\mathrm{Si3} \# 10$ & $4.0429(18)$ & & & \\
\hline & Si9 & $3.7252(14)$ & & & \\
\hline & N5 & $2.935(5)$ & & & \\
\hline & N7\#9 & $3.227(5)$ & & & \\
\hline & N6 & $3.000(4)$ & & & \\
\hline
\end{tabular}

Note: * Rb5 is located beside a twofold axis; the distances for the Rb5 generated by symmetry are given in the cif file (Supplementary materials).

\section{Experimental Section}

All manipulations were performed under inert atmosphere in an argon filled MBraun Labmaster 130 $\mathrm{G}$ glove box. Schlenk tubes were used as reaction vessels. $\mathrm{Ni}(\mathrm{CO})_{2}\left(\mathrm{PPh}_{3}\right)_{2}(\mathrm{ABCR})$ was used without further purification. 18-crown-6 (1,4,7,10,13,16-hexaoxacyclooctadecane; Sigma-Aldrich Chemie Gmbh, Munich, Germany) was sublimated and then stored under argon. The solvent liquid ammonia was stored over potassium to remove traces of water before it was condensed on the reactands. For the synthesis of the precursor material $\mathrm{K}_{6} \mathrm{Rb}_{6} \mathrm{Si}_{17} 0.294 \mathrm{~g}(7.5 \mathrm{mmol}) \mathrm{K}, 0.644 \mathrm{~g}(7.5 \mathrm{mmol}) \mathrm{Rb}$ and $0.5 \mathrm{~g}$ (17.8 mmol) Si were placed in a duran glass ampoule, which had been dried in vacuo before, and sealed under argon. The ampoule was placed in a second quartz glass ampoule for safety and heated to 
$460{ }^{\circ} \mathrm{C}$ using a heating rate of $25^{\circ} \mathrm{C} / \mathrm{h}$. The temperature was kept for $72 \mathrm{~h}$, afterwards the product was cooled down using a cooling rate of $20^{\circ} \mathrm{C} / \mathrm{h} .0 .12 \mathrm{~g}(0.098 \mathrm{mmol})$ of the blue black precursor phase, $0.063 \mathrm{~g}(0.098 \mathrm{mmol})$ of $\mathrm{Ni}(\mathrm{CO})_{2}\left(\mathrm{PPh}_{3}\right)_{2}$ and $0.08 \mathrm{~g}(0.30 \mathrm{mmol}) 18$-crown-6 were weighed in a Schlenk tube. Approximately $15 \mathrm{~mL}$ of dry ammonia were condensed on the reactands at $-78{ }^{\circ} \mathrm{C}$. The solution immediately changed color from yellow to red after shaking. The reaction vessel was kept at $-40{ }^{\circ} \mathrm{C}$, where an increase in color could be observed. After four weeks red, rod shaped crystals suitable for $\mathrm{X}$-ray structure analysis could be obtained

\section{Conclusions}

The here presented crystal structure of $\left[\mathrm{K}_{0.28} \mathrm{Rb}_{7.72} \mathrm{Si}{ }_{9} \mathrm{Ni}(\mathrm{CO})_{2}\right]_{2} \cdot 16 \mathrm{NH}_{3}$ proves the stability of the silicide complex anion $\left[\left\{\mathrm{Ni}(\mathrm{CO})_{2}\right\}_{2}\left(\mu-\mathrm{Si}_{9}\right)_{2}\right]^{8-}$ without any chelating additives in solid state, but the presence of 18-crown-6 for solubility enhancement might be a necessity.

\section{Author Contributions}

Markus Hamberger and Stefanie Gärtner carried out experimental work (synthesis, crystallization and X-ray structure determination), Stefanie Gärtner prepared the manuscript, Nikolaus Korber designed and conceived the study.

\section{Supplementary Information}

Supplementary materials can be accessed at: http://www.mdpi.com/2073-4352/5/3/0275/s1.

\section{Conflicts of Interest}

The authors declare no conflict of interest.

\section{References}

1. Scharfe, S.; Kraus, F.; Stegmaier, S.; Schier, A.; Fässler, T.F. Zintl ions, cage compounds, and intermetalloid clusters of group 14 and group 15 elements. Angew. Chem. Int. Ed. 2011, 50, 3630-3670.

2. Scharfe, S.; Fässler, T.F. Polyhedral nine-atom clusters of tetrel elements and intermetalloid derivatives. Phil. Trans. R. Soc. A 2010, 368, 1265-1284.

3. Gärtner, S.; Korber, N. 1.09-Zintl anions. In Comprehensive Inorganic Chemistry II, 2nd ed.; Reedijk, J., Poeppelmeier, K., Eds.; Elsevier: Amsterdam, The Netherlands, 2013; pp. 251-267.

4. Gärtner, S.; Korber, N. Polyanions of group 14 and group 15 elements in alkali and alkaline earth metal solid state compounds and solvate structures. In Zintl Ions Principles and Recent Developments; Fässler, T.F., Ed.; Springer-Verlag: Berlin, Germany; Heidelberg, Germany, 2011; Volume 140, pp. 25-56.

5. Ugrinov, A.; Sevov, S.C. $\mathrm{Ge}_{9}=\mathrm{Ge}_{9}=\mathrm{Ge}_{9}=\mathrm{Ge}_{9}{ }^{8-}$ : A linear tetramer of nine-atom germanium clusters, a nanorod. Inorg. Chem. 2003, 42, 5789-5791.

6. Hull, M.W.; Sevov, S.C. Functionalization of nine-atom deltahedral zintl ions with organic substituents: Detailed studies of the reactions. J. Am. Chem. Soc. 2009, 131, 9026-9037. 
7. Chapman, D.J.; Sevov, S.C. Tin-based organo-zintl ions: Alkylation and alkenylation of $\mathrm{Sn}_{9}{ }^{4-}$. Inorg. Chem. 2008, 47, 6009-6013.

8. Goicoechea, J.M.; Sevov, S.C. Deltahedral germanium clusters: Insertion of transition-metal atoms and addition of organometallic fragments. J. Am. Chem. Soc. 2006, 128, 4155-4161.

9. Zhou, B.B.; Denning, M.S.; Kays, D.L.; Goicoechea, J.M. Synthesis and isolation of $\left[\mathrm{Fe} @ \mathrm{Ge}_{10}\right]^{3-}$ : A pentagonal prismatic zintl ion cage encapsulating an interstitial iron atom. J. Am. Chem. Soc. 2009, 131, 2802-2803.

10. Scharfe, S.; Fässler, T.F.; Stegmaier, S.; Hoffmann, S.D.; Ruhland, K. [Cu@Sn9 $]^{3-}$ and $\left[\mathrm{Cu} @ \mathrm{~Pb}_{9}\right]^{3-}$ : Intermetalloid clusters with endohedral $\mathrm{Cu}$ atoms in spherical environments. Chem. Eur. J. 2008, 14, 4479-4483.

11. Goicoechea, J.M.; Sevov, S.C. Ligand-free deltahedral clusters of silicon in solution: Synthesis, structure, and electrochemistry of $\mathrm{Si}^{2-}$. Inorg. Chem. 2005, 44, 2654-2658.

12. Goicoechea, J.M.; Sevov, S.C. Naked deltahedral silicon clusters in solution: Synthesis and characterization of $\mathrm{Si}_{9}{ }^{3-}$ and $\mathrm{Si}_{5}{ }^{2-}$. J. Am. Chem. Soc. 2004, 126, 6860-6861.

13. Joseph, S.; Suchentrunk, C.; Korber, N. Dissolving silicides: Syntheses and crystal structures of new ammoniates containing $\mathrm{Si}_{5}{ }^{2-}$ and $\mathrm{Si}_{9}{ }^{4-}$ polyanions and the role of ammonia of crystallisation. Z. Naturforsch. B 2010, 65, 1059-1065.

14. Joseph, S.; Suchentrunk, C.; Kraus, F.; Korber, N. Si ${ }^{4-}$ anions in solution-structures of the solvates $\mathrm{Rb}_{4} \mathrm{Si}_{9} \cdot 4.75 \mathrm{NH}_{3}$ and $\left[\mathrm{Rb}\left(18\right.\right.$-crown-6)] $\mathrm{Rb}_{3} \mathrm{Si}_{9} \cdot 4 \mathrm{NH}_{3}$, and chemical bonding in $\mathrm{Si}_{9}{ }^{4-}$. Eur. J. Inorg. Chem. 2009, 2009, 4641-4647.

15. Goicoechea, J.M.; Sevov, S.C. Organozinc derivatives of deltahedral zintl ions: Synthesis and characterization of closo- $\left[\mathrm{E}_{9} \mathrm{Zn}\left(\mathrm{C}_{6} \mathrm{H}_{5}\right)\right]^{3-}(\mathrm{E}=\mathrm{Si}$, Ge, Sn, $\mathrm{Pb})$. Organometallics 2006, 25, 4530-4536.

16. Waibel, M.; Kraus, F.; Scharfe, S.; Wahl, B.; Fässler, T.F. $(\mathrm{MesCu})_{2}\left(\eta^{3}-\mathrm{Si}_{4}\right)^{4-}$ : A mesitylcopper-stabilized tetrasilicide tetraanion. Angew. Chem. Int. Ed. 2010, 49, 6611-6615.

17. Joseph, S.; Hamberger, M.; Mutzbauer, F.; Hartl, O.; Meier, M.; Korber, N. Chemistry with bare silicon clusters in solution: A transition-metal complex of a polysilicide anion. Angew. Chem. Int. Ed. 2009, 48, 8770-8772.

18. Queneau, V.; Todorov, E.; Sevov, S.C. Synthesis and structure of isolated silicon clusters of nine atoms. J. Am. Chem. Soc. 1998, 120, 3263-3264.

19. Hoch, C.; Wendorff, M.; Rohr, C. Synthesis and crystal structure of the tetrelides $\mathrm{A}_{12} \mathrm{M}_{17}(\mathrm{~A}=\mathrm{Na}$, $\mathrm{K}, \mathrm{Rb}, \mathrm{Cs} ; \mathrm{M}=\mathrm{Si}, \mathrm{Ge}, \mathrm{Sn})$ and $\mathrm{A}_{4} \mathrm{~Pb}{ }_{9}(\mathrm{~A}=\mathrm{K}, \mathrm{Rb})$. J. Alloys Compd. 2003, 361, 206-221.

(C) 2015 by the authors; licensee MDPI, Basel, Switzerland. This article is an open access article distributed under the terms and conditions of the Creative Commons Attribution license (http://creativecommons.org/licenses/by/4.0/). 